\title{
KUALITAS HIDUP LANSIA: KAITANNYA DENGAN INTEGRITAS DIRI, INTERAKSI SUAMI-ISTRI, DAN FUNGSI KELUARGA
}

\author{
Dwi Kurniati Putri ${ }^{1^{*}}$, Diah Krisnatuti ${ }^{2}$, Herien Puspitawati ${ }^{2}$ \\ ${ }^{1}$ Program Studi Ilmu Keluarga dan Perkembangan Anak, Sekolah Pascasarjana, Institut Pertanian Bogor, \\ Bogor 16680, Indonesia \\ ${ }^{2}$ Departemen IImu Keluarga dan Konsumen, Fakultas Ekologi Manusia, Institut Pertanian Bogor, \\ Bogor 16680, Indonesia
}

"E-mail: kurniatiputridwi@gmail.com

\begin{abstract}
Abstrak
Lansia perempuan yang memiliki pasangan akan kesulitan merasakan kebermaknaan hidup jika tidak ditunjang dengan keberfungsian keluarga dan terjalinnya interaksi suami-istri yang baik. Penelitian ini bertujuan untuk menganalisis pengaruh karakteristik lansia, karakteristik keluarga, integritas diri, interaksi suami-istri, dan fungsi keluarga terhadap kualitas hidup lansia. Contoh dalam penelitan ini adalah lansia perempuan berusia 60 tahun ke atas yang tinggal di Perdesaanperdesaan (Kecamatan Nanggung, Kabupaten Bogor) dan perkotaan (Kecamatan Bogor Barat, Kota Bogor), berstatus menikah, dan mempunyai tempat tinggal pribadi atau tidak menumpang dengan anak dengan total contoh berjumlah 120 lansia perempuan. Teknik pemilihan responden menggunakan simple random sampling. Hasil uji beda menunjukkan bahwa fungsi keluarga lansia di perkotaan lebih tinggi capaiannya dibandingkan di perdesaan. Dimensi fungsi agama, fungsi cinta kasih, fungsi ekonomi, dan fungsi pembinaan lingkungan pada keluarga lansia di perkotaan lebih tinggi capaiannya dibandingkan di perdesaan. Perbedaan signifikan pada dimensi kemandirian dan kebebasan, lingkungan rumah dan tetangga, kesejahteraan dan psikologis emosional, keadaan keuangan, serta aktivitas keagamaan dan waktu luang antara lansia di perdesaan dan perkotaan. Kualitas hidup lansia di perkotaan lebih tinggi capaiannya daripada lansia di perdesaan. Kualitas hidup lansia dipengaruhi secara signifikan oleh lama pendidikan istri, jumlah keluhan penyakit, pendapatan per kapita, dan fungsi keluarga.
\end{abstract}

Kata kunci : fungsi keluarga, integritas diri, interaksi suami-istri, kualitas hidup, lansia

\section{Quality of Life of Elderly: Its Relation with Self-Integrity, Husband-Wife Interaction, and Family Functions}

\begin{abstract}
Married elderly women will have difficulty to feel the meaningfulness of life if not supported by the functioning of the family and the good interactions between husband and wife. This study aims to analyze the influence of older adults sociodemographic, family characteristics, self integrity, husband-wife interaction, and family functions on quality of life of older adults. Samples of this study were older women aged 60 years old, who lived in rural (Nanggung Sub-District, Bogor Regency) and urban (West Bogor Sub-District, Bogor City), married, and lived in their own house or no-coresidence with children, and an amount of 120 older women. The technique of selecting respondents using simple random sampling. The result of T-tests show that the function of elderly families in urban areas is higher than in rural areas. Dimensions of religion, affection, economic, and environmental development function in elderly families in urban areas is higher than in rural areas. There were significant differences in the functions of independence, control over life and freedom, home and neighbourhood, psychological and emotional well-being, financial circumstances, leisure and activities between the older adults in rural and urban areas. The quality of life of older adults in urban areas was higher than the older adults in rural areas. Quality of life of older adults was significantly influenced by length of wife education, number of chronic illness, revenue per capita, and family function.
\end{abstract}

Keywords: family function, husband-wife interaction, older adult, quality of life, self integrity

\section{PENDAHULUAN}

Jumlah penduduk lansia mengalami peningkatan yang cukup signifikan, hampir lima dekade Jumlah penduduk lansia mengalami peningkatan yang cukup signifikan yang ditunjukkan dari peningkatan persentase lansia di Indonesia sekitar dua kali lipat selama lima dekade terakhir (1971-2017) yaitu menjadi 
8,97 persen (23,4 juta). Kelompok lansia Indonesia didominasi dengan usia 60-69 tahun (lansia muda) yang persentasenya mencapai 5,65 persen dari penduduk Indonesia dan tinggal di perdesaan (BPS, 2017). Data BPS Provinsi Jawa Barat (2017) melaporkan bahwa jumlah penduduk lansia tahun 2017 sebanyak 4,16 juta jiwa meningkat dari tahun 2015 (3,77 juta jiwa). Berdasarkan proyeksi penduduk, pada tahun 2021, jumlah penduduk lansia diperkirakan sebanyak 5,07 juta jiwa atau sebesar 10,04 persen dari penduduk total Jawa Barat. Kondisi ini menunjukkan bahwa Jawa Barat sudah memasuki ageing population. Ageing population merupakan pertumbuhan dalam jumlah dan proporsi umur orang yang lebih tua dalam suatu populasi. Kondisi tersebut menuntut lansia harus dapat menyesuaikan diri terhadap perubahan status ekonomi dan kondisi fisik serta mengembangkan kegiatan baru yang lebih cocok (BPS, 2017).

Dalam teori perkembangan psikososial Erikson, lansia berada pada periode terakhir tahapan perkembangan psikososial integrity vs despair (Santrock, 2002), yang berarti lansia memiliki kesempatan melihat kembali perjalanan hidup ke belakang. Integrity merasakan kebermaknaan hidup dalam tatanan sosial dan mempunyai pemaknaan terhadap kesuksesan secara integratif dari masa lalu, sekarang, dan masa depan. Sementara, despair bermakna bahwa lansia menganggap masa tua dengan pandangan negatif, danragu-ragu, dan putus asa sehingga menyebabkan lansia sulit menerima dirinya telah menjadi tua (Papalia, Old, \& Feldman, 2008).

Pandangan tersebut menunjukkan bahwa integritas diri lansia menjadi penting untuk menentukan apakah lansia akan merasa terintegrasi hidupnya atau putus asa. Integritas diri lansia adalah kemampuan lansia menyikapi pengalaman masa lalu dengan bijaksana, menerima, dan menjalani kehidupan saat ini tanpa ragu dan putus asa (Santrock, 2002). Penelitian Dezutter, Toussaint dan Leijssen (2016) juga mengemukakan bahwa usia secara signifikan berkorelasi negatif dengan integritas diri, yang artinya semakin bertambah usia maka integritas diri lansia akan menurun. Penelitian lain dari Westerhof, Bohlmeijer dan McAdams (2017) menyatakan integritas diri juga berpengaruh dengan kondisi kesehatan lansia; semakin baik kondisi kesehatan lansia akan meningkatkan integritas diri lansia dan berpengaruh terhadap kesejahteraan lansia. Selain kesehatan fisik, kesehatan mental/psikologis juga berpengaruh dengan kesejahteraan emosional. Penelitian sebelumnya menemukan bahwa dimensi dari kualitas hidup yang berhubungan dengan integritas diri adalah kesejahteraan emosional (Bowling, Hankins, Windle, Bilotta, \& Grant, 2013).

Interaksi suami-istri bermanfaat untuk menjaga keselarasan fungsi keluarga, terutama dalam memfasilitasi pembagian peran, tugas, dan pekerjaan. Interaksi suami-istri merupakan sebuah hubungan timbal balik antara suami istri yang memperlihatkan suatu proses pengaruh dan memengaruhi (Puspitawati, 2012). Penelitian Tam dan Neysmith (2006) menemukan bahwa industrialisasi dan urbanisasi membawa perubahan secara signifikan, salah satunya adalah menurunnya kepatuhan istri terhadap suami sebagai kepala rumah tangga, dan berdampak pada interaksi pasangan. Sementara interaksi suami-istri yang dapat terjalin dengan optimal akan mengoptimalkan juga kualitas perkawinan (Allendorf \& Ghimire, 2013). Hasil penelitian Herawati, Kumalasari, Musthofa, dan Tyas (2018) menunjukkan bahwa besar keluarga berhubungan positif dengan interaksi keluarga, artinya semakin banyak jumlah anggota keluarga akan meningkatkan interaksi keluarga. Tinggi rendahnya interaksi keluarga juga disebabkan oleh adanya dukungan sosial (keluarga luas dan tetangga) yang diberikan kepada istri, sehingga dapat memberikan dampak positif pada istri untuk mempertahankan kedekatan hubungan melalui interaksi yang baik (Herawati et al., 2018).

Ketika anggota keluarga saling berinteraksi untuk menyelesaikan masalah secara efektif maka akan mengoptimalkan keberfungsian keluarga (Eyberg \& Robinson, 2009). Orang tua yang memiliki riwayat penyakit kronis merasa bahwa keluarganya tidak berfungsi dalam merawat lansia, padahal lansia juga termasuk sumber daya keluarga (Chaves, Amaral, Nelas, Coutinho, \& Dionisio, 2013). Cao, Jiang, Li, Hui dan Li (2013) menemukan bahwa semakin optimal pelaksanaan fungsi keluarga maka kesejahteraan emosional yang dirasakan individu semakin baik. Hal tersebut dapat terjadi karena adanya dukungan dari lingkungan sosialnya. Canjie, Lexin, Weiquan, Ying dan Shengmao (2017) menemukan ada beberapa faktor yang memengaruhi fungsi keluarga yaitu usia, gender, status perkawinan, tingkat pendidikan, dan kondisi ekonomi. Lansia yang memiliki pasangan dan/atau anakanak dan/atau cucu dalam keluarga mempunyai skor fungsi keluarga yang lebih 
baik dibandingkan lansia yang keluarganya hanya terdiri dari saudara kandung dan/atau keponakan (Oliveira, Pavarini, Orlandi \& Mendiondo, 2014). Penelitian lain juga menemukan bahwa kebanyakan lansia mengalami kesulitan beraktivitas dalam kegiatan sehari-hari sehinggalansia membutuhkan keberfungsian keluarga untuk meningkatkan kualitas hidup lansia (Wang \& Yuang, 2016).

Pada penelitian sebelumnya terkait kualitas hidup lansia, Netuveli, Wiggins, Hildon, Montgomery dan Blane (2006) mengukur kualitas hidup berdasarkan aspek objektif dan subjektif. Pengukuran kualitas hidup objektif didasarkan pada sumber daya dalam bentuk uang, pengetahuan, mental, hubungan sosial, dan lain-lain. Pada penelitian ini, kualitas hidup akan didekati dengan perspektif subjektif dan didasarkan pada delapan dimensi subjektif yaitu dimensi kehidupan, kesehatan, hubungan dan aktivitas sosial, kemandirian dan kebebasan, lingkungan rumah dan tetangga, kesejahteraan dan psikologis emosional, keadaan keuangan, serta aktivitas keagamaan dan waktu luang Bowling et al. (2013). Interaksi suami-istri pada penelitian Bowling et al. (2013), responden penelitian adalah lansia laki-laki dan perempuan yang berumur 65 tahun ke atas yang tinggal di rumah. Beberapa penelitian terhadap lansia telah dilakukan seperti Dezutter et al. (2016) menguji hubungan pemaafan, integritas ego, dan gejala depresi; Herawati et al. (2018) yang menganalisis dukungan sosial, interaksi keluarga, dan kualitas perkawinan, Wang dan Zhao (2012) yang meneliti pengaruh fungsi keluarga dan dukungan sosial pada lansia di perkotaan , dan juga Canjie et al. (2017) yang menganalisis depresi dan resiliensi sebagai variabel mediasi fungsi keluarga yang memengaruhi kualitas hidup lansia. Penelitian ini mengukur kualitas hidup berdasarkan persepsi lansia perempuan yang tinggal di perdesaan dan perkotaan ditinjau dari integritas diri, interaksi suami-istri, dan fungsi keluarga.

Chokkanatan dan Natarajan (2017) menemukan bahwa kualitas hidup lansia akan berkurang apabila memiliki pendapatan yang rendah. Riwayat penyakit kronis yang dimiliki oleh orang tua akan memengaruhi komponen fisik kualitas hidup yang berkaitan dengan kesehatan (Tahreen \& Shahed, 2014). Bertambahnya usia lansia juga berkaitan dengan kualitas hidup (Chan, Chien, Thompson, Chiu, \& Lam, 2006; Gouveia, Matos, \& Schouten, 2016). Baernholdt, Yan,
Hinton, Rose, dan Mattos (2012) menyebutkan bahwa kepuasaan hidup lansia di perdesaan lebih rendah dibandingkan lansia perkotaan karena lansia di perdesaan memiliki tingkat depresi lebih tinggi seperti terbatasnya layanan kesehatan, tidak adanya program-program sosial yang menunjang kualitas hidup lansia, fungsi sosial rendah.. Wilayah tempat tinggal merupakan salah satu faktor pembeda kualitas hidup lansia (Dong \& Simon, 2010; Li, Zhang, Zhang, Zhang, \& Zhou, 2013). Berdasarkan wilayah tempat tinggal, penelitian Tavares, Bolina, Dias, Ferreira dan Haas (2014) menemukan bahwa lansia di perkotaan memiliki kualitas hidup lebih tinggi dibandingkan lansia di perdesaan. Oleh karena itu, penelitian ini bertujuan untuk menganalisis perbedaan karakteristik lansia, karakteristik keluarga, integritas diri, interaksi suami-istri, fungsi keluarga, dan kualitas hidup berdasarkan wilayah tempat tinggal; dan menganalisis pengaruh karakteristik lansia, karakteristik keluarga, integritas diri, interaksi suami-istri, dan fungsi keluarga terhadap kualitas hidup lansia di perdesaan dan perkotaan.

\section{METODE}

Penelitian ini menggunakan desain cross sectional study. Waktu penelitian terdiri dari persiapan, pengumpulan data, pengolahan data, analisis data, dan penulisan laporan.. Lokasi penelitian di wilayah Kecamatan Nanggung, Kabupaten Bogor sebagai representasi wilayah perdesaan dan Kecamatan Bogor Barat, Kota Bogor sebagai representasi wilayah perkotaan dan dipilih secara purposive. Populasi penelitian ini adalah keluarga lanjut usia (lansia) yang tinggal di lokasi terpilih. Responden penelitian adalah lansia perempuan berusia 60 tahun ke atas, dan tinggal di lokasi penelitian, berstatus menikah, mempunyai tempat tinggal pribadi atau tidak menumpang dengan anak, dan bersedia untuk dijadikan partisipasn penelitian. Dari setiap kecamatan terpilih masing-masing dipilih dua desa/kelurahan yaitu Desa Pangkal Jaya, Kecamatan Nanggung ( $\mathrm{N}=46$ keluarga), Desa Bantar Karet, Kecamatan Nanggung ( $\mathrm{N}=52$ keluarga), Kelurahan Cilendek Barat, Kecamatan Bogor Barat ( $\mathrm{N}=68$ keluarga), dan Kelurahan Semplak, Kecamatan Bogor Barat $(\mathrm{N}=51$ keluarga). Selanjutnya, responden dipilih secara acak (simple random sampling) dari kerangka contoh tersebut dan melibatkan 120 lansia perempuan sebagai responden.

Data primer diperoleh langsung dari responden melalui wawancara dengan menggunakan 
kuisioner, meliputi karakteristik lansia (usia istri, lama pendidikan istri, dan jumlah keluhan penyakit), karakteristik keluarga (usia suami, lama pendidikan suami, jumlah anggota keluarga, dan pendapatan per kapita), integritas diri, interaksi suami-istri, fungsi keluarga, dan kualitas hidup. Integritas diri adalah kemampuan lansia menyikapi pengalaman masa lalu dengan bijaksana, menerima, dan menjalani kehidupan saat ini tanpa ragu dan putus asa (Santrock, 2002). Kuisioner integritas diri dikembangkan dari dua kuesioner yaitu Accepting The Past (ACPAST) yang dikembangkan oleh Santor dan Zuroff (1994) dan Integrity Subscale from The Modified Eriksonian Psyschosocial Inventory yang dikembangkan oleh Hearn et al. (2012) dan terdiri dari 15 pertanyaan menggunakan 5 skala penilaian ( $1=$ Sangat tidak setuju; 2=Tidak setuju; 3=Netral; 4=Setuju; 5=Sangat setuju) dengan nilai Cronbach's alpha 0,861.

Interaksi suami-istri dalam penelitian ini merujuk pada konsep hubungan timbal balik antara suami istri lansia yang berkaitan dengan komunikasi dan bonding (Puspitawati, 2012). Kuisioner interaksi suami-istri dikembangkan peneliti dengan mengacu pada Chuang (2005) dan Herawati et al. (2018) dan terdiri dari 18 ipertanyaan menggunakan 4 skala penilaian ( $1=$ Tidak pernah; $2=$ Kadangkadang; 3=Sering; 4=Selalu) dengan nilai Cronbach's alpha 0,791.

Fungsi keluarga dalam penelitian ini menggunakan konstruk yang terkait dengan peran dan tanggung jawab keluarga dalam menjalankan tugas-tugasnya dengan tetap mengupayakan kesejahteraan keluarga (Epstein, Baldwin, \& Bioshop, 1983). Kuisioner fungsi keluarga menggunakan konsep 8 fungsi keluarga (fungsi agama, sosial budaya, cinta kasih, perlindungan, reproduksi, sosialisasi dan pendidikan, ekonomi, dan pembinaan lingkungan) yang tercantum dalam Peraturan Pemerintah RI Nomor 87 tahun 2014 dan Herawati (2018). Kuesioner ini terdiri dari 26 pertanyaan menggunakan 4 skala penilaian (1=Tidak pernah; 2=Jarang; 3=Sering; 4=Selalu) dengan nilai Cronbach's alpha 0,818 .

Kualitas hidup dalam penelitian ini merujuk pada persepsi lansia tentang kondisi kehidupan saat ini yang berkaitan dengan kehidupan, kesehatan, hubungan dan aktivitas sosial, kemandirian dan kebebasan, lingkungan rumah dan tetangga, kesejahteraan dan psikologis emosional, keadaan keuangan, serta aktivitas keagamaan dan waktu luang berdasarkan konstruk dari Bowling et al. (2013). Kuisioner kualitas hidup terdiri dari 26 pertanyaan menggunakan 5 skala penilaian (1=Sangat tidak setuju; $2=$ Tidak setuju; 3=Netral; 4=Setuju; 5=Sangat setuju) dengan nilai Cronbach's alpha 0,812.

Data yang telah dikumpulkan kemudian diolah melalui proses editing, coding, scoring, entering, cleaning, dan analisis data. Nilai skor integritas diri, interaksi suami-istri, fungsi keluarga, dan kualitas hidup ditransformasikan dalam bentuk indeks 0-100. Pengolahan dan analisis data dilakukan dengan menggunakan program Microsoft Excel dan Statistical Package for Social Science (SPSS). Analisis yang dilakukan meliputi analisis deskriptif, uji beda $t$-test, dan uji regresi linear berganda dengan hipotesa utama bahwa integritas diri, interaksi suami-istri, dan fungsi keluarga memengaruhi kualitas hidup lansia dalam penelitian ini.

\section{HASIL}

\section{Karakteristik Lansia dan Keluarga}

Hasil penelitian memperlihatkan rata-rata usia lansia perempuan di perdesaan dan perkotaan yaitu 63,6 tahun dan 63,9 tahun, dengan ratarata pendidikan di perdesaan dan perkotaan masing-masing adalah 1,5 tahun dan 7,5 tahun. Hasil uji beda menunjukkan bahwa lama pendidikan lansia di perkotaan lebih tinggi secara signifikan dibandingkan lansia di perdesaan. Secara keseluruhan, jumlah keluhan penyakit lansia sebanyak satu jenis penyakit dengan keluhan penyakit yang paling banyak dikeluhkan adalah darah tinggi, rematik, dan asma. Rata-rata usia suami lansia di perdesaan dan perkotaan yaitu 69,4 dan 68,9 tahun dengan rata-rata pendidikan perdesaan dan perkotaan yaitu 3,1 tahun dan 4,2 tahun hampir seluruh suami lansia di perdesaan $(96,7 \%)$ memiliki lama pendidikan setara Sekolah Dasar (SD) dan sekitar 36,7 persen suami di perkotaan memiliki lama pendidikan setara dengan Sekolah Menengah Atas (SMA). Hasil uji beda menunjukkan bahwa lama pendidikan suami lansia di perkotaan lebih tinggi dibandingkan lama pendidikan suami lansia di perdesaan. Hampir tiga per empat keluarga lansia $(70,0 \%)$ berada pada kelompok keluarga kecil, dengan ratarata jumlah anggota keluarga sebanyak 4 orang. 
Tabel 1 Sebaran lansia berdasarkan kategori indeks variabel integritas diri, interaksi suami-istri, dan fungsi keluarga

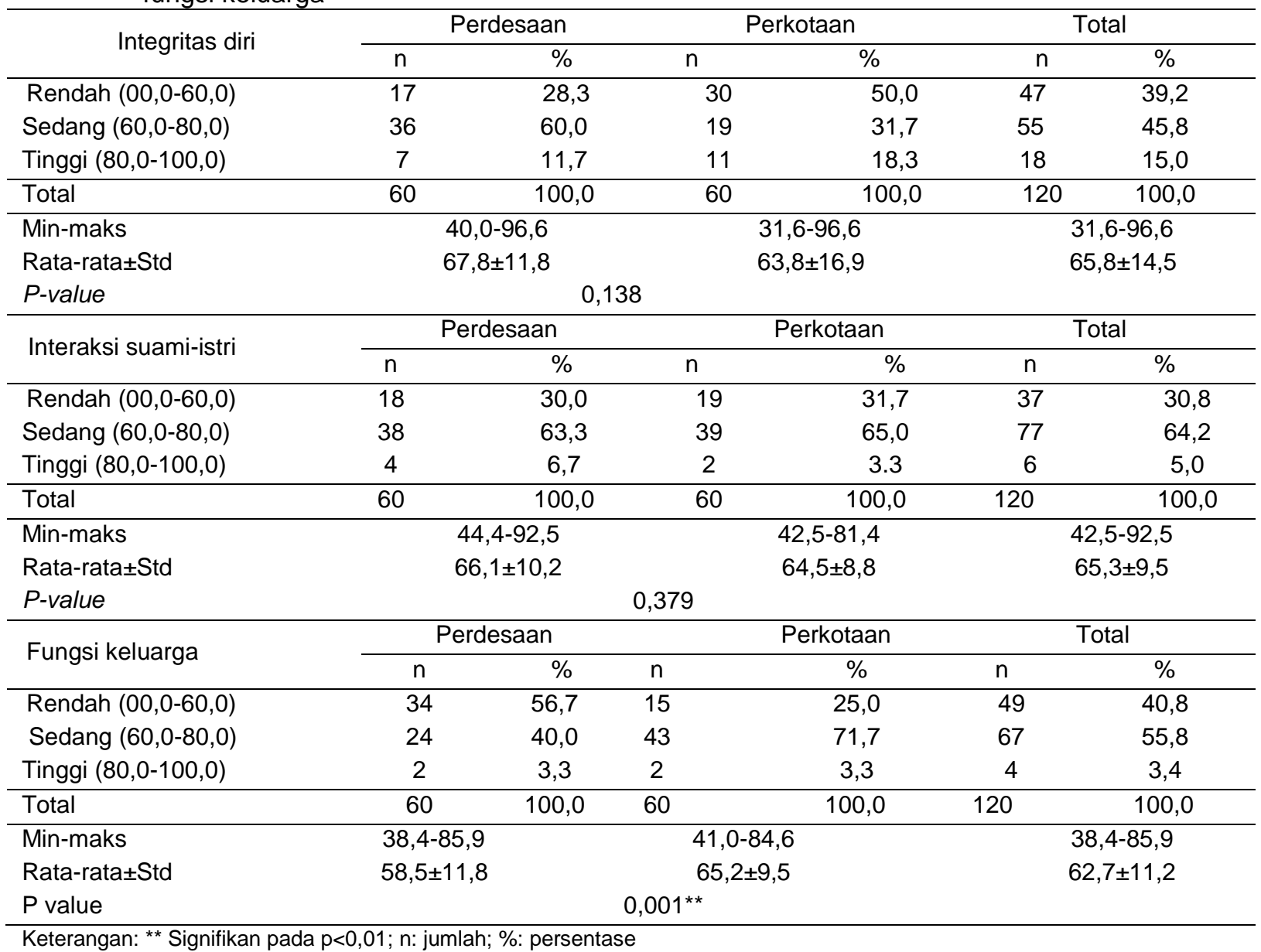

Rata-rata pendapatan per kapita keluarga lansia di perdesaan yaitu Rp268.000,00 (kisaran Rp50.000,00 hingga Rp1.250.000,00), sedangkan keluarga lansia di perkotaan yaitu Rp796.000,00 (kisaran Rp83.333,00 hingga Rp5.000.0000,00). Lebih lanjut, pendapatan per kapita keluarga lansia di perkotaan lebih besar secara signifikan dibandingkan pendapatan per kapita keluarga lansia di perdesaan. Selain itu, mayoritas sample terkategori keluarga miskin di perdesaan $(40,8 \%)$ daripada di perkotaan $(36,7 \%)$.

\section{Integritas Diri}

Secara umum, hampir setengah lansia dalam penelitian ini $(45,8 \%)$ berada dalam integritas diri kategori sedang dengan rata-rata indeks sebesar 65,8 . Selain itu, lebih dari setengah lansia di perdesaan $(60,0 \%)$ berada dalam integritas diri kategori sedang sedangkan setengah lansia di perkotaan (50,0\%) terkategori rendah. Selanjutnya, hampir seluruh lansia (93,3\%) terbiasa melakukan aktivitas sehari-hari secara mandiri, merasa senang berbagi pengalaman hidup untuk memberikan solusi kepada orang lain $(78,3 \%)$, serta tidak takut menjadi tua dan mendekati kematian $(70,9 \%)$. Sekitar 41,7 persen lansia merasa sakit ketika memikirkan masa lalu, ada kekecewan di dalam hidup yang tidak bisa dilupakan $(45,8 \%)$, dan ada pengalaman masa kecil yang membuat lansia marah ketika mengingatnya (53,3\%). Selanjutnya, tidak terdapat perbedaan signifikan pada variabel integritas diri antara lansia yang tinggal di perdesaan dan perkotaan.

\section{Interaksi suami-istri}

Hasil penelitian memperlihatkan, lebih dari setengah lansia di perdesaan $(63,3 \%)$ dan sekitar 65 persen lansia di perkotaan memiliki indeks interaksi suami-istri yang terkategori sedang. Penelitian memperlihatkan, istri tidak pernah meneriaki atau membentak-bentak suami ketika berperilaku buruk $(79,1 \%)$, membantu suami mengerjakan sesuatu atau menyelesaikan suatu masalah $(65,8 \%)$, dan mengalah ketika berdebat dengan suami $(95,8 \%)$. Akan tetapi, masih ada beberapa pencapaian yang belum optimal seperti istri enggan menunjukkan rasa kasih kepada suami $(53,4 \%)$ dan suami jarang berdiskusi atau meminta pendapat istri akan keputusan 
penting dalam keluarga $(64,1 \%)$. Selanjutnya, tidak terdapat perbedaan signifikan pada variabel interaksi suami-istri antara lansia yang tinggal di perdesaan dan perkotaan.

\section{Fungsi Keluarga}

Secara umum, setengah lansia perempuan yang terlibat dalam penelitian ini $(55,8 \%)$ memiliki fungsi keluarga terkategori sedang dengan rataan indeks 62,7 . Hal ini dapat dilihat bahwa sebagian besar lansia saling menghormati agama atau kepercayaan orang lain $(95,0 \%)$, hidup rukun dan saling menghormati antar tetangga $(97,5 \%)$, sering berkunjung/bersilahturahmi ke rumah kerabat $(74,2 \%)$, dan pasangan lansia saling mengingatkan untuk saling mengatur keuangan ketika pengeluaran melebihi batas $(73,3 \%)$. Namun, penelitian ini juga menemukan lansia jarang membantu kegiatan kerja bakti di lingkungan tempat tinggal $(68,3 \%)$, jarang memberi nasihat terpuji dengan pasangan $(62,5 \%)$, dan lansia jarang melakukan olahraga secara teratur $(73,3 \%)$. Lebih lanjut, fungsi keluarga lansia di perkotaan lebih baik secara signifikan dibandingkan lansia di perdesaan.

Secara keseluruhan, pencapaian terendah dimensi fungsi keluarga pada lansia di perdesaan yaitu dimensi fungsi cinta kasih. Hasil uji beda menunjukkan perbedaan signifikan yaitu lansia di perkotaan lebih baik dalam hal keberfungsian cinta kasih dibandingkan lansia di perdesaan. Pencapaian fungsi keluarga terendah pada lansia di perkotaan yaitu dimensi fungsi reproduksi. Rataan tertinggi pencapaian dimensi fungsi keluarga lansia pada dua wilayah tempat tinggal (perdesaan dan perkotaan) pada dimensi pertama yaitu fungsi agama. Tabel 2 memperlihatkan, terdapat perbedaan signifikan pada fungsi agama yaitu lansia di perkotaan lebih baik secara signifikan dalam hal keagamaan dibandingkan lansia di perdesaan.

Dimensi fungsi agama. Rata-rata indeks fungsi agama pada lansia perdesaan adalah sebesar 73,6, sedangkan lansia di perkotaan sebesar 89,6 atau berada dalam kategori tinggi. Pada dimensi fungsi agama, terdapat perbedaan yang signifikan antara lansia di perdesaan dan perkotaan yaitu lansia di perkotaan memiliki fungsi agama lebih baik dibandingkan lansia di perdesaan. Dimensi fungsi agama antara lain membaca kitab suci dan saling mengingatkan ketika lalai menjalankan perintah agama.
Tabel 2 Indeks pencapaian dimensi fungsi keluarga

\begin{tabular}{lccc}
\hline \multicolumn{1}{c}{$\begin{array}{c}\text { Fungsi } \\
\text { Keluarga }\end{array}$} & Perdesaan & Perkotaaan & $\begin{array}{c}\text { P- } \\
\text { Value }\end{array}$ \\
\hline $\begin{array}{l}\text { Fungsi } \\
\text { agama }\end{array}$ & 73,6 & 89,6 & $0,000^{* *}$ \\
$\begin{array}{l}\text { Fungsi } \\
\text { sosial } \\
\text { budaya }\end{array}$ & 67,4 & 58,3 & $0,002^{* *}$ \\
$\begin{array}{l}\text { Fungsi cinta } \\
\text { kasih } \\
\text { Fungsi }\end{array}$ & 40,6 & 48,3 & $0,036^{*}$ \\
$\begin{array}{l}\text { perlindungan } \\
\text { Fungsi } \\
\text { reproduksi }\end{array}$ & 65,0 & 68,6 & 0,279 \\
$\begin{array}{l}\text { Fungsi } \\
\text { sosialisasi } \\
\text { dan } \\
\text { pendidikan }\end{array}$ & 62,4 & 46,3 & 0,366 \\
$\begin{array}{l}\text { Fungsi } \\
\text { ekonomi }\end{array}$ & 54,3 & 62,0 & 0,893 \\
$\begin{array}{l}\text { Fungsi } \\
\text { pembinaan } \\
\text { lingkungan }\end{array}$ & 61,7 & 70,2 & $0,000^{* *}$ \\
\hline $\begin{array}{l}\text { Rata-rata } \\
\text { indeks }\end{array}$ & 58,5 & 78,5 & $0,000^{* *}$ \\
\hline $\begin{array}{l}\text { Keterangan: }{ }^{*} \text { Signifikan pada p<0,05; } \\
\text { p<0,01 Signifikan pada }\end{array}$ & & \\
\hline
\end{tabular}

Dimensi fungsi sosial budaya. Hasil uji beda pada dimensi fungsi sosial budaya menunjukkan terdapat perbedaan signifikan yaitu lansia di perdesaan lebih baik dalam fungsi sosial budaya dibandingkan lansia di perkotaan. Dimensi sosial budaya antara lain lansia membantu kegiatan kerja bakti dan tetangga yang kesulitan di lingkungan tempat tinggal.

Dimensi fungsi cinta kasih. Lansia di perdesaan memiliki rata-rata indeks dimensi fungsi cinta kasih sebesar 40,6 sedangkan lansia di perkotaan yaitu 48,3. Hasil uji beda menunjukkan bahwa terdapat perbedaan signifikan antara lansia di perdesaan dan lansia di perkotaan, yaitu lansia di perkotaan lebih baik dalam hal fungsi cinta kasih dibandingkan lansia di perdesaan. Lebih lanjut, pada dimensi fungsi cinta kasih lansia mengungkapkan harapan untuk mencapai keharmonisan keluarga dan suami lansia membantu istri dalam hal pekerjaan rumah tangga.

Dimensi fungsi perlindungan. Rata-rata indeks fungsi perlindungan secara keseluran terkategori sedang. Dimensi fungsi perlindungan antara lain lansia selalu mendiskusikan dengan pasangan jika terdapat ketidaknyaman di dalam rumah tangga, membantu merawat anggota keluarga yang sakit, membantu menyediakan 
obat-obatan dirumah seperti obat merah, tanaman obat, P3K, serta lansia selalu memaafkan kesalahan yang dilakukan pasangan atau anggota keluarga.

Dimensi fungsi reproduksi. Hasil penelitian menunjukkan bahwa tidak terdapat perbedaan yang signifikan antara lansia di perdesaan dan di perkotaan pada dimensi fungsi reproduksi. Secara spesifik, pada dimensi fungsi reproduksi para lansia saling membantu dalam mengasuh atau merawat anak dan cucu bersama pasangan. Selain itu, para lansia saling berbagi pengetahuan tentang kesehatan, dan membiasakan olahraga secara teratur.

Dimensi fungsi sosialisasi dan pendidikan. Secara keseluruhan, rata-rata indeks dimensi fungsi sosialisasi dan pendidikan pada lansia di perdesaan $(62,4)$ dan lansia di perkotaan $(62,0)$ terkategori sedang. Dimensi fungsi sosialisasi dan pendidikan antara lain lansia mengikuti kegiatan sosial di lingkungan sekitar rumah.

Dimensi fungsi ekonomi. Hasil uji beda menunjukkan bahwa lansia di perkotaan lebih baik dalam hal keberfungsian ekonomi dibandingkan lansia di perdesaan. Dimensi fungsi ekonomi antara lain lansia sudah mengingatkan suami untuk saling mengatur keuangan ketika pengeluaran melebihi batas, lansia menyisihkan pendapatan untuk keperluan darurat, dan lansia mendahulukan kebutuhan utama dari kebutuhan yang lain.

Dimensi fungsi pembinaan dan lingkungan. Secara umum, rata-rata indeks dimensi fungsi pembinaan dan lingkungan pada lansia di perdesaan $(61,7)$ dan lansia di perkotaan $(78,5)$ terkategori sedang. Hasil uji beda memperlihatkan, lansia di perkotaan lebih baik dalam hal pembinaan lingkungan dibandingkan lansia di perdesaan. Dimensi fungsi pembinaan dan lingkungan antara lain lansia sudah membuang sampah di tempatnya dan lansia sudah mengurangi penggunaan kantong plastik.

\section{Kualitas Hidup}

Hasil penelitian menunjukkan bahwa dua per tiga lansia di perdesaan $(66,7 \%)$ dan sekitar 70 persen lansia di perkotaan memiliki indeks kualitas hidup terkategori sedang (Tabel 3). Hasil uji beda menunjukkan terdapat perbedaan signifikan yaitu kualitas hidup lansia di perkotaan lebih baik dibandingkan lansia di perdesaan.
Tabel 3 Sebaran lansia berdasarkan kategori indeks variabel kualitas hidup

\begin{tabular}{|c|c|c|c|c|c|c|}
\hline \multirow{2}{*}{$\begin{array}{l}\text { Kualitas } \\
\text { hidup }\end{array}$} & \multicolumn{2}{|c|}{ Perdesaan } & \multicolumn{2}{|c|}{ Perkotaan } & \multicolumn{2}{|c|}{ Total } \\
\hline & $\mathrm{n}$ & $\%$ & $n$ & $\%$ & & $\%$ \\
\hline $\begin{array}{l}\text { Rendah } \\
(00,0- \\
60,0)\end{array}$ & 19 & 31,7 & 3 & 5,0 & 22 & 1 \\
\hline $\begin{array}{l}\text { Sedang } \\
(60,0- \\
80,0)\end{array}$ & 40 & 66,7 & 42 & 70,0 & 82 & 6 \\
\hline $\begin{array}{l}\text { Tinggi } \\
(80,0- \\
100,0)\end{array}$ & 1 & 1,7 & 15 & 25,0 & 16 & 1 \\
\hline Total & 60 & 100,0 & 60 & 100,0 & 12 & 1 \\
\hline $\begin{array}{l}\text { Rata- } \\
\text { rata } \pm S t d\end{array}$ & \multicolumn{2}{|c|}{$64,3 \pm 7,57$} & \multicolumn{2}{|c|}{$73,3 \pm 9,22$} & \multicolumn{2}{|c|}{68} \\
\hline Min-maks & \multicolumn{2}{|c|}{$49,0-80,7$} & \multicolumn{2}{|c|}{$55,7-97,1$} & & 49 \\
\hline $\mathrm{P}$ value & \multicolumn{4}{|c|}{$0,000^{* *}$} & & \\
\hline
\end{tabular}

Pencapaian kualitas hidup terendah pada wilayah perdesaan yaitu dimensi keadaan keuangan (Tabel 3). Hasil penelitian menunjukkan, terdapat perbedaan signifikan pada dimensi keuangan yaitu lansia di perkotaan lebih baik perihal keuangan dibandingkan lansia di perdesaan. Pencapaian kualitas hidup terendah pada wilayah perkotaan yaitu pada dimensi kesehatan. Rataan tertinggi pencapaian dimensi kualitas hidup lansia di perdesaan yaitu pada dimensi hubungan dan aktivitas sosial, sedangkan pada lansia di perkotaan yaitu dimensi lingkungan rumah dan tetangga. Hasil uji beda memperlihatkan bahwa lebih banyak lansia di perkotaan memiliki lingkungan rumah yang nyaman dibandingkan lansia di perdesaan.

Dimensi kehidupan. Lansia di pedesaan dan perkotaan memiliki rata-rata indeks dimensi kehidupan cukup baik. Dimensi kehidupan antara lain lansia begitu menikmati kehidupan di usia sekarang dan kehidupan membuat lansia terpuruk.

Dimensi kesehatan. Rata-rata indeks dimensi kesehatan untuk masing-masing wilayah tempat tinggal berbeda, yaitu pada lansia di perdesaan sebesar 70,2 dan pada lansia di perkotaan sebesar 66,6. Dimensi kesehatan antara lain lansia mempunyai kesehatan fisik yang baik dan rasa sakit tidak membatasi lansia untuk berdiam diri dirumah.

Dimensi hubungan dan aktivitas sosial. Hasil penelitian menemukan bahwa tidak terdapat perbedaan signifikan antara lansia di perdesaan dan perkotaan pada dimensi 
hubungan dan aktivitas sosial. Dimensi hubungan dan aktifitas sosial antara lain lansia merasa bahwa keluarga, teman, atau tetangga selalu ada jika dibutuhkan dan lansia ingin lebih menikmati hidup dengan bertemu orang banyak.

Dimensi kemandirian dan kebebasan. Tabel 4 memperlihatkan terdapat perbedaan signifikan pada dimensi kemandirian dan kebebasan yaitu lansia di perkotaan lebih mandiri dan bebas dibandingkan lansia di perdesaan Dimensi kemandirian dan kebebasan antara lain lansia merasa cukup sehat melakukan hal-hal secara mandiri. Dimensi lingkungan rumah dan tetangga. Rata-rata indeks dimensi lingkungan rumah dan tetangga pada lansia di perdesaan lebih rendah $(75,0)$ dibandingkan lansia di perkotaan $(98,3)$. Dimensi lingkungan rumah dan tetangga antara lain lansia memiliki lingkungan rumah dan tetangga yang nyaman serta toko, layanan kesehatan, dan fasilitas yang ada di sekitar lansia memadai.

Dimensi kesejahteraan dan psikologis emosional. Hasil uji beda memperlihatkan bahwa lansia di perkotaan memiliki kesejahteraan psikologis emosional lebih baik dibandingkan lansia di perdesaan. Salah satu dimensi kesejahteraan dan psikologis emosial yaitu lansia merasa paling beruntung dibandingkan teman-teman yang lain.

Tabel 4 Indeks pencapaian dimensi kualitas hidup

\begin{tabular}{|c|c|c|c|}
\hline Kualitas hidup & Perdesaan & Perkotaaan & $\begin{array}{r}P- \\
\text { Value }\end{array}$ \\
\hline Kehidupan & 70,4 & 69,6 & 0,774 \\
\hline Kesehatan & 70,2 & 66,6 & 0,301 \\
\hline $\begin{array}{l}\text { Hubungan } \\
\text { dan aktivitas } \\
\text { sosial }\end{array}$ & 76,5 & 76,3 & 0,951 \\
\hline $\begin{array}{l}\text { Kemandirian } \\
\text { dan } \\
\text { kebebasan }\end{array}$ & 56,7 & 68,0 & $0,000^{* *}$ \\
\hline $\begin{array}{l}\text { Lingkungan } \\
\text { rumah dan } \\
\text { tetangga }\end{array}$ & 75,0 & 98,3 & $0,000^{* *}$ \\
\hline $\begin{array}{l}\text { Kesejahteraan } \\
\text { dan psikologis } \\
\text { emosional }\end{array}$ & 62,7 & 67,0 & $0,038^{*}$ \\
\hline $\begin{array}{l}\text { Keadaan } \\
\text { keuangan }\end{array}$ & 39,4 & 70,8 & $0,000^{* *}$ \\
\hline $\begin{array}{l}\text { Aktivitas dan } \\
\text { waktu luang }\end{array}$ & 64,2 & 70,2 & $0,003^{* *}$ \\
\hline $\begin{array}{l}\text { Rata-rata } \\
\text { indeks }\end{array}$ & 64,3 & 73,3 & $0,000^{* *}$ \\
\hline
\end{tabular}

Dimensi keadaan keuangan. Hasil penelitian menunjukkan bahwa terdapat perbedaan signifikan antara lansia di perdesaan dan perkotaan dalam hal dimensi keuangan yaitu lansia di perkotaan lebih baik perihal keuangan dibandingkan lansia di perdesaan. Dimensi keuangan antara lain lansia mempunyai cukup uang untuk membiayai kebutuhan sehari-hari dan lansia mampu membeli apapun yang mereka inginkan.

Dimensi aktivitas dan waktu luang. Ratarata indeks dimensi aktivitas dan waktu luang lansia di perdesaan $(64,2)$ lebih rendah dibandingkan lansia di perkotaan $(70,2)$. Lebih lanjut, terkait dimensi aktivitas dan waktu luang, yaitu para lansia lebih suka melakukan hobi untuk menghabiskan waktu luang tersebut.

\section{Pengaruh Karakteristik Lansia, Karakteristik Keluarga, Integritas Diri, Interaksi Suami-Istri, dan Fungsi Keluarga terhadap Kualitas Hidup}

Hasil penelitian menemukan bahwa lansia yang mengalami penambahan jumlah keluhan penyakit setiap tahunnya akan menurunkan kualitas hidup. Selanjutnya, semakin tinggi pendidikan istri, pendapatan per kapita, dan fungsi keluarga akan meningkatkan kualitas hidup lansia. Secara keseluruhan, variabelvariabel dalam penelitian ini menggambarkan 77,7 persen faktor yang memengaruhi kualitas hidup lansia, sisanya sebesar 22,3 persen dipengaruhi oleh variabel lainnya di luar penelitian.

Berdasarkan hasil uji regresi linear berganda menunjukkan bahwa variabel jumlah keluhan penyakit $(B=-1,547, \quad p=0,01)$ berpengaruh negatif signifikan terhadap kualitas hidup. Setiap kenaikan jumlah keluhan penyakit per satu tahun dapat menurunkan indeks kualitas hidup sebesar 1,547 poin (Tabel 5). Hasil temuan tersebut bermakna semakin bertambahnya jumlah keluhan penyakit pada lansia setiap tahunnya akan menurunkan kualitas hidup lansia.

Tabel 5 juga memperlihatkan bahwa lama pendidikan istri $(B=0,528, p=0,01)$, pendapatan per kapita keluarga $(B=3,714 E-6, p=0,01)$, dan fungsi keluarga $(B=0,400, p=0,01)$ memiliki pengaruh positif signifikan terhadap kualitas hidup lansia. Artinya, peningkatan pendidikan formal yang ditempuh istri akan meningkatkan indeks kualitas hidup sebesar 0,528 poin. 
Tabel 5 Model regresi pengaruh karakteristik lansia, karakteristik keluarga, integritas diri, interaksi suami-istri dan fungsi keluarga terhadap kualitas hidup lansia

\begin{tabular}{|c|c|c|c|}
\hline Variabel & B & $\beta$ & $\begin{array}{c}\text { Signifik } \\
\text { ansi }\end{array}$ \\
\hline Konstanta & 38,613 & & $0,000^{* *}$ \\
\hline $\begin{array}{l}\text { Usia istri } \\
\text { (tahun) }\end{array}$ & $-0,039$ & $-0,019$ & 0,684 \\
\hline $\begin{array}{l}\text { Lama } \\
\text { pendidikan } \\
\text { istri (tahun) }\end{array}$ & 0,528 & 0,263 & $0,000^{* *}$ \\
\hline $\begin{array}{l}\text { Jumlah } \\
\text { keluhan } \\
\text { penyakit } \\
\text { (jenis) }\end{array}$ & $-1,547$ & $-0,134$ & $0,004^{* *}$ \\
\hline $\begin{array}{l}\text { Pendapatan } \\
\text { per kapita } \\
\text { (rupiah) }\end{array}$ & $3,714 \mathrm{E}-6$ & 0,261 & $0,000^{* *}$ \\
\hline $\begin{array}{l}\text { Integritas diri } \\
\text { (indeks) }\end{array}$ & 0,025 & 0,034 & 0,474 \\
\hline $\begin{array}{l}\text { Interaksi } \\
\text { suami-istri } \\
\text { (indeks) }\end{array}$ & 0,085 & 0,086 & 0,160 \\
\hline $\begin{array}{l}\text { Fungsi } \\
\text { keluarga } \\
\text { (indeks) }\end{array}$ & 0,400 & 0,475 & $0,000^{* *}$ \\
\hline $\begin{array}{l}\text { Adjusted R } \\
\text { square }\end{array}$ & & & 0,777 \\
\hline $\mathrm{F}$ & & & 60,209 \\
\hline Sig & & & $0,000^{\star *}$ \\
\hline Keterangan: & $\begin{array}{l}\text { Signifikan } \\
\text { standardize }\end{array}$ & $p<$ & $\begin{array}{l}\text {; B: Beta } \\
\text { ardized }\end{array}$ \\
\hline
\end{tabular}

Selanjutnya, setiap kenaikan pendapatan per kapita setiap bulannya dapat meningkatkan indeks kualitas hidup lansia sebesar 3,714 poin, artinya peningkatan pendapatan per kapita setiap bulannya dapat meningkatkan kualitas hidup lansia. Selain itu, setiap kenaikan skor fungsi keluarga sebanyak satu satuan dapat meningkatkan indeks kualitas hidup sebesar 0,400 poin, artinya peningkatan fungsi keluarga yang dirasakan lansia terhadap keluarganyamaka menyebabkan lansia memiliki kualitas hidup yang baik.

\section{PEMBAHASAN}

Hasil penelitian menunjukkan usia lansia terketegori lansia muda (60-69) sesuai dengan kategori BPS (2017) dengan lama pendidikan lansia di perkotaan lebih tinggi dibandingkan di perdesaan. Hal ini sejalan dengan penelitian Dong dan Simon (2010) dan Vogelsang (2016) yang menemukan bahwa lansia di perdesaan cenderung memiliki pendidikan lebih rendah dibandingkan lansia di perkotaan. Penelitian Sunarti (2013) juga menemukan bahwa pendidikan istri dan suami keluarga di perkotaan lebih tinggi dibandingkan keluarga di perdesaan. Rata-rata jumlah keluhan penyakit lansia sebanyak satu jenis keluhan penyakit dengan jumlah keluhan jenis penyakit lansia di perkotaan lebih tinggi dibandingkan lansia di perdesaan. Berdasarkan hasil penelitian jumlah keluhan penyakit yang paling banyak dikeluhkan yaitu darah tinggi. Kemenkes RI (2013) mengemukakan bahwa separuh lansia mengalami keluhan kesehatan sebulan terakhir, namun keluhan kesehatan tidak selalu mengakibatkan terganggunya aktivitas seharihari. Keluhan kesehatan yang paling banyak dikeluhkan lansia seperti asam urat, darah tinggi, rematik, dll. perdesaanHasil temuan Levasseur et al. (2015) menemukan bahwa pendapatan keluarga lansia di perkotaan lebih tinggi dibandingkan di perdesaan dan sejalan dengan hasil penelitian ini. Baerholdt et al. (2012) mengemukakan bahwa pendapatan keluarga yang rendah menunjukkan bahwa keluarga tersebut memiliki sumber daya sedikit.

Secara keseluruhan, lansia memiliki indeks integritas diri cukup baik. Hal ini ditunjukkan dari sekitar delapan per sepuluh lansia merasa nyaman membicarakan hal-hal yang terjadi di masa lalu dan sebagian besar lansia merasakan kedamaian dalam kehidupan yang dijalani. Menurut Dezutter et al. (2016), salah satu indikator lansia berintegritas yaitu mampu mengatasi pengalaman negatif dari masa lalu dengan berusaha memaafkan kesalahan diri sendiri dan orang lain. Selanjutnya, rata-rata indeks variabel interaksi suami-istri berada dalam kategori sedang. Hasil penelitian menemukan sekitar sembilan per sepuluh lansia selalu menyediakan waktu untuk berinteraksi dengan pasangan dan sebagian besar lansia tidak menegur suami yang bersalah di depan orang lain. Pada penelitian ini, lansia di perdesaan mengaku tidak pernah bermusuhan dengan suami dibandingkan lansia di perkotaan. Burns et al. (2017) menjelaskan bahwa permusuhan suami istri jarang terjadi ketika pasangan memasuki usia tua.

Hasil uji beda menunjukkan bahwa fungsi keluarga lansia di perkotaan lebih baik dibandingkan lansia di perdesaan. Kondisi ini dikarenakan lansia di perkotaan memiliki fungsi agama (membaca kitab suci dan pasangan lansia saling mengingatkan ketika lalai menjalankan perintah agama) lebih baik dibandingkan lansia di perdesaan. Lansia di perdesaan jarang mengungkapkan harapan untuk mencapai keharmonisan keluarga dibandingkan lansia di perkotaan dan lansia 
di perkotaan lebih baik dalam fungsi ekonomi seperti menyisihkan pendapatan untuk keperluan darurat dibandingkan lansia perdesaan. Menurut Sunarti (2013), keluarga di perkotaan memiliki dimensi tipologi keluarga lebih baik dibandingkan keluarga di perdesaan. Keluarga di perkotaan memiliki waktu kebersamaan dan pemaknaan akan waktu kebersamaan yang lebih tinggi dibandingkan keluarga di perdesaan. Cheng et al. (2017) mengemukakan bahwa lansia di perkotaan memiliki nilai spritual dan status ekonomi lebih baik dibandingkan lansia di perdesaan. Sejalan dengan penelitian ini, hasil uji beda menunjukkan bahwa fungsi agama dan fungsi ekonomi lansia di perkotaan lebih baik dibandingkan lansia di perdesaan.

Hasil uji beda menunjukkan terdapat perbedaan signifikan pada kualitas hidup lansia di perkotaan yang lebih baik dibandingkan lansia di perdesaan. Hal tersebut dikarenakan lansia di perkotaan lebih menikmati kehidupan dan lebih bahagia di usia sekarang dibandingkan lansia di.perdesaan. Sebagian besar lansia di perkotaan merasa bahwa keluarga, teman, atau tetangga selalu ada jikalau mereka butuhkan, hampir sebagian besar lansia di perkotaan mempunyai cukup uang untuk membiayai kebutuhan sehari-hari, lansia di perkotaan lebih mampu membeli apapun yang diinginkan, dan secara keseluruhan toko, layanan kesehatan, dan fasilitas lain di sekitar lansia perkotaan lebih memadai dibandingkan lansia di perdesaan. Faktafakta tersebut mendukung penelitian Baerholdt et al. (2012) dan Tavares et al. (2014). Penelitian menunjukkan perbedaan signifikan pada dimensi keuangan yaitu lansia di perkotaan lebih baik perihal keuangan dibandingkan lansia di perdesaan. Penelitian Cheng et al. (2017) menemukan bahwa rendahnya status ekonomi lansia di perdesaan menyebabkan rendahnya daya beli. Menurut Levasseur et al. (2015), lansia di perkotaan memiliki lingkungan tempat tinggal yang nyaman karena jarak rumah antar tetangga dekat, tersedianya layanan kesehatan, dan fasilitas lainnya di perkotaan lebih memadai dibandingkan di perdesaan (Karamivand, Bastani, \& Haghani, 2018). Hasil-hasil penelitian tersbeut sejalan dengan penelitian ini yang menemukan bahwa lebih banyak lansia di perkotaan memiliki lingkungan rumah yang nyaman dibandingkan lansia di perdesaan.
Hasil penelitian ini menegaskan bahwa jumlah keluhan penyakit berpengaruh negatif signifikan terhadap kualitas hidup. Kondisi ini berarti lansia yang memiliki jumlah penyakit lebih banyak akan merasa kurang nyaman dan tidak bahagia sehingga menurunkan kualitas hidup yang berkaitan dengan kesehatan. Hal ini sejalan dengan penelitian Jivraj, Nazroo, Vanhoutte dan Chandola (2014) yang menemukan bahwa lansia yang memiliki penyakit kronis akan terhambat dalam melakukan aktivitas sehari-hari sehingga mengakibatkan kesejahteraan subjektif lansia menurun. Netuveli et al. (2006), CondeSala, Ortiz, Perxas dan Olmo (2016), Eliasi, Rasi dan Tavakoli (2017) menemukan bahwa riwayat penyakit akan memengaruhi kualitas hidup lansia yaitu semakin bertambahnya keluhan penyakit lansia, maka akan menurunkan kualitas hidup.

Hasil penelitian juga menemukan bahwa lama pendidikan dan pendapatan berpengaruh positif signifikan dengan kualitas hidup. Hal tersbeut mengindikasikan bahwa semakin tinggi pendidikan formal yang ditempuh lansia maka pengetahuan dan kemampuan memperoleh sumbe rdayanya semakin baik sehingga dapat memiliki pendapatan lansia yang optimal. Adanya pengetahuan lansia yang baik dapat mengoptimalkan pengelolaan pendapatan setiap bulannya sehingga lansia merasa bahagia dan meningkatkan kualitas hidup lansia. Hal ini sejalan dengan penelitian Netuveli et al. (2006) yang menemukan bahwa semakin tinggi pendidikan dan pendapatan lansia maka akan meningkatkan kualitas hidupnya. Selanjutnya, CondeSala et al. (2016), Eliasi et al. (2017) menyatakan bahwa semakin tinggi pendapatan maka akan meningkatkan kualitas hidup lansia. Penghasilan yang tinggi secara konsisten dikaitkan dengan kualitas hiidup yang lebih baik (Chokkanatan \& Natarajan, 2017).

Hasil penelitian juga menemukan bahwa fungsi keluarga berpengaruh positif signifikan terhadap kualitas hidup lansia. Hal ini berarti apabila keberfungsian lansia tercapai dengan baik maka akan meningkatkan kualitas hidup lansia. Keberfungsian keluarga lansia ini ditunjukkan dengan adanya keterkaitan keluarga dan dukungan keluarga dalam mencapai fungsi keluarga sehingga lansia merasa bahagia dan mengoptimalkan kualitas hidup lansia. Penelitian sebelumnya yang dilakukan Sanchez et al. (2011) menemukan bahwa fungsi keluarga 
berpengaruh positif signifikan terhadap kualitas hidup yang terdiri dari empat dimensi yaitu dukungan sosial, kepuasan, kesejahteraan mental dan fisik, serta ketersediaan waktu luang. Cheng et al. (2017) menemukan bahwa fungsi keluarga berkaitan dengan salah satu dimensi kualitas hidup yaitu dimensi kesehatan. Penelitian Cao et al. (2013) juga menemukan bahwa semakin baik fungsi keluarga, maka semakin baik kesejahteraan emosional yang lansia rasakan. Kesejahteraan emosional merupakan salah satu dimensi dari kualitas hidup (Bowling et al., 2013). Wang dan Huang (2006) menyatakan bahwa fungsi keluarga diperlukan untuk meningkatkan kualitas hidup lansia.

Penelitian ini memiliki keterbatasan yaitu tidak dapat digeneralisasikan pada usia lanjut di Indonesia dikarenakan pemilihan lokasi menggunakan desain purposive dan sampel dalam penelitian ini hanya dilakukan pada lansia perempuan. Diharapkan penelitian lain dapat mengisi kesenjangan pengetahuan terkait kualitas hidup lansia perempuan yang memiliki pasangan dilihat dari perspektif suami dengan cara mewawancarai suami lansia dalam pengambilan data. Pengetahuan lain terkait kualitas hidup lansia dapat diukur dari aspek lain, misal tugas perkembangan lansia dan gaya hidup lansia.

\section{SIMPULAN DAN SARAN}

Hasil uji beda menunjukkan bahwa lama pendidikan istri dan suami lansia di perkotaan lebih tinggi dibandingkan lansia di perdesaan. Pendapatan per kapita keluarga lansia di perkotaan lebih besar dibandingkan pendapatan per kapita keluarga lansia di perdesaan. Rata-rata pendapatan per kapita keluarga lansia di perdesaan yaitu Rp268.000,00, sedangkan keluarga lansia di perkotaan yaitu Rp796.000,00. Fungsi keluarga dan kualitas hidup lansia di perkotaan lebih baik dibandingkan lansia di perdesaan. Berdasarkan uji regresi kualitas hidup dipengaruhi negatif signifikan oleh jumlah keluhan penyakit, sedangkan faktor yang berpengaruh positif signifikan terhadap kualitas hidup yaitu lama pendidikan lansia, pendapatan per kapita, dan fungsi keluarga.

Berdasarkan hasil penelitian, kualitas hidup dipengaruhi oleh jumlah keluhan penyakit, lama pendidikan lansia, pendapatan per kapita, dan fungsi keluarga. Oleh karena itu, diharapkan keluarga sebagai unit terkecil dalam masyarakat dapat menjaga, merawat, dan mendukung perkembangan lansia. Pengoptimalan fungsi keluarga lansia sangat dibutuhkan agar dapat meningkatkan kualitas hidup secara signifikan. Pemanfaatan posyandu lansia diharapkan berperan dalam mewujudkan lansia yang sehat jasmani dan rohani serta membantu mewujudkan kemandirian finansial lansia, misalnya pemanfaatan sumber daya lokal menjadi produk yang layak jual. Pemerintah diharapkan dapat lebih memperhatikan lansia khususnya lansia di perdesaan terutama memfasilitasi akan kebutuhan pendidikan, kemandirian finansial, dan layanan kesehatan. Bagi pemerintah dan instansi diharapkan penelitian ini dapat menjadi acuan untuk membuat kebijakan dalam bidang keluarga khususnya kualitas hidup keluarga lanjut usia.

\section{DAFTAR PUSTAKA}

[BPS] Badan Pusat Statistika Provinsi Jawa Barat. (2017). Profil Lansia Provinsi Jawa Barat 2017. Jawa Barat (ID): BPS.

[BPS] Badan Pusat Statistika. (2017). Statistik Penduduk Lanjut Usia 2017. Jakarta (ID): BPS.

[Kemenkes RI]. Kementrian Kesehatan Republik Indonesia. (2013). Gambaran Kesehatan Lanjut Usia di Indonesia. Jakarta (ID): Kemenkes RI.

Allendorf, K., \& Ghimire, D. J. (2013). Determinants of marital quality in an arranged marriage society. Social Science Research, 42(1), 59-70. doi: 10.1016/j.ssresearch.2012.09.002.

Baernholdt, M., Yan, G., Hinton, I., Rose, K., \& Mattos, M. (2012). Quality of life in rural and urban adults 65 years and older: findings from the national health and nutrition examination survey. The Journal of Rural Health, 1-9. doi: 10.1111/j.17480361.2011.00403.x.

Bowling, A., Hankins, M., Windle, G., Bilotta, C., \& Grant, R. (2013). A short measure of quality of life in older age: the performance of the brief older people's quality of life questionnaire (OPQOLbrief). Archives of Gerontology and Geriatrics, 56 (2013), 181-187. doi: 10.1016/j.archger.2012.08.012.

Burns, J. W., Post, K. M., Smith, D. A., Porter, L. S., Buvanendran, A., Fras, A. M., Keefe, F. J. (2017). Spouse criticism and hostility during marital interaction. PAIN, 159(1), 25-32. doi: 10.1097/j.pain. 0000000000001037 . 
Canjie, L., Lexin, Y., Weiquan, L., Ying, Z., \& Shengmao, P. (2017). Depression and resilence mediates the effect of family function on quality of live of the elderly. Archives of Gerontology and Geriatrics, 71, 34-42. doi: 10.1016/j.archger.2017.02.011.

Cao, X., Jiang, X., Li, X., Hui, Lo., Li, R. (2013). Family functioning and its predictors among disaster bereaved individuals in china : eighteen monts after the wenchuan earthquake. PloS ONE, 8(4), e60738. doi: 10.1371/journal.pone.0060738.

Chan, S. W., Chien, W. T., Thompson, D. R., Chiu, H. F., \& Lam, L. (2006). Quality of life measures for depressed and nondepressed chinese older people. Int $J$ Geriatr Psychiatry, 21, 1086-1092. doi: 10.1002/gps.1611.

Chaves, C. B., Amaral, O. P., Nelas, P. A., Coutinho, E. C., \& Dionisio, R. M. (2013). Assessment of family functionality among the elderly with chronic illness. The European Journal of Counselling Psychology, 2, 130-144. doi: 10.5964/ejcop.v2i2.31.

Cheng, Y., Zhang, L., Wang, F., Zhang, P., Ye, B., \& Liang Y. (2017). The effects of family structure and function on mental health during China's transition: a crosssectional analysis. BMC Family Practice, 18, 59. doi: 10.1186/s12875-017-0630-4.

Chokkanatan, S., \& Natarajan, A. (2017). Perceived quality of life following mistreatment in rural india. $J$ Gerontol $B$ Psychol Sci Soc Sci, 00, 1-12. doi: 10.1093/geronb/gbx043.

Chuang, Y. C. (2005). Effects of interaction pattern on family harmony and well being: test of interpersonal theory, relational model theory, and confucian ethics. sian journal of social psychology, 8, 272-291. doi: 10.1111/j.1467-839X.2005.00174.x.

CondeSala, J. L., Ortiz, C. P., Perxas, L. C., \& Olmo, J. G. (2016). Quality of life in people aged $65+$ in europe: associated factors and models of social welfareanalysis of data from the share project (wave 5). Qual Life Res, 26(4), 10591070. doi: 10.1007/s11136-016-1436-x.

Dezutter, J., Toussaint, L., \& Leijssen, M. (2016). Forgiveness, ego-integrity, and depressive symptoms in communitydwelling and residential elderly adults. $J$
Gerontol B Psychoi Sci Soc Sci, 71(5), 786-797. doi: 10.1093/geronb/gbu146.

Dong, X., \& Simon, M. A. (2010). Health and aging in a Chinese population: urban and rural disparities. Geriatr Gerontol Int, 10, 85-93. doi: 10.1111/j.14470594.2009.00563.x.

Eliasi, L. G., Rasi, H. A., \& Tavakoli, A. (2017). Factors affecting quality of life among elderly population in iran. Humanities and Social Sciences, 5(1), 26-30. doi: 10.11648/j.hss.20170501.15.

Epstein, N. B., Baldwin, \& Bioshop, D. S. (1983). The McMaster family assessmeny device. Journal of Marital and Family Therapy, 9, 2, 171-180.

Eyberg, \& Robinson. (2009). Parent-child interaction training : effect of family functioning. Journal of Clinical Child Psychology, 11(2), 130-137. doi: 10.1080/15374418209533076.

Gouveia, O. M., Matos, A. D., \& Schouten, M. J. (2016). Social networks and quality of life elderly persons: a review and critical analysis of literature. Social networks and quality of life of older people, 19(6), 10311040. doi: 10.1590/198122562016019.160017.

Hearn, S., Saulnier, G., Strayer, J., Glenham, M., Koopman, R., \& Marcia, J. E. (2012). Between integrity and despair : toward construct validation of erikson's eight stage. J Adult Dev, 19, 1-20. doi: 10.1007/s10804-011-9126-y.

Herawati, T. (2018). Penanaman dan Penerapan Nilai Karakter melalui 8 Fungsi Keluarga. Jakarta (ID): BKKBN.

Herawati, T., Kumalasari, B., Musthofa., \& Tyas, F. P. S. (2018). Dukungan sosial, interaksi keluarga, dan kualitas perkawinan pada keluarga suami istri bekerja. Jur. Ilm. Kel. \& Kons, 11(1), 1-12. doi: 10.24156/jikk.2018.11.1.1.

Jivraj, S., Nazroo, J., Vanhoutte, B., \& Chandola, T. (2014). Aging and subjective well-being in later life. Journals of Gerontology, Series B: Psychological Sciences and Social Sciences, 69(6), 930-941. doi:10.1093/geronb/gbu006.

Karamivand, V., Bastani, F., \& Haghani, $H$. (2018). Supportive needs of urban and rural elders. J Aging Geriatr Psychiatry, 2(2), 1-6.

Levasseur, M., Cohen, A. A., Dubois, M. F., Genereux, M., Richard, L., Therrien, F. H., 
\& Payette, H. (2015). Environmental factors associated with social participation of older adults living in metropolitan, urban, and rural areas: the nuage study. American Journal of Public Health, 105, 8, 1718-1725.

Li, M., Zhang, Y., Zhang, Z., Zhang, Y., \& Zhou, L. (2013). Rural-urban differences in the long-term care of the disabled eederly in China. PloS ONE, 8(11). doi: 10.1371/journal.pone.0079955.

Netuveli, G., Wiggins, R. D., Hildon, Z., Montgomery, S. M., \& Blane, D. (2006). Quality of life at older ages: evidence from the english longitudinal study of aging (wave 1). Journal of Epidemiology and Community Health, 60, 357-363. doi: 10.1136/jech.2005.040071.

Oliveira, S. C., Pavarini, S. C., Orlandi, F. D., \& Mendiondo, M. S. (2014). Family functionality: a study of Brazilian institutionalized elderly individuals. Archives of Gerontology Geriatrics, 58, 170-176. doi: 10.1016/j.archger.2013.07.003.

Papalia, D. E., Old, S. W., \& Feldman, R. D. (2008). Psikologi Perkembangan. Akanwar, penerjemah. Jakarta, Penerbit Kencana. Terjemahan dari: Human Development. Ed ke-9.

Puspitawati, H. (2012). Gender dan Keluarga : Konsep dan Realita di Indonesia. Bogor (ID): IPB Press.

Sanchez, E. R., Penaranda, A., Baltar, A. L., Perez, D., Marcoz, M. A., Alonso, M. C., \& Ortiz, L. G. (2011). Relationships between quality of life and family function in caregiver. BMC Family Practice, 12(19), 1-7. doi: 10.1186/1471-2296-12-19.

Santor, D. A., \& Zuroff, D. C. (1994). Depressive symptoms : effect of negative affectivity and failing to accept the past. Journal of Personality Assessment, 63, 2. doi: 10.1207/s15327752jpa6302_9.
Santrock, J. W. (2002). Life-Span Development. Sixth Edition. New York, Brown and Benchmark Publisher.

Sunarti, E. (2013). Tipologi keluarga di wilayah perdesaan dan perkotaan. Jur. IIm. Kel. \&. Kons, 6(2), 73-81. doi: 10.24156/jikk.2013.6.2.73.

Tahreen, S. F., \& Shahed, S. (2014). Relationship between diri integrity, despair, social support and health related quality of life. Pakistan Journal of Social and Clinical Psychology, 12, 26-33.

Tam, S., \& Neysmith, S. (2006). Disrespect and isolation: elder abuse in Chinese communities. Canadian Journal on Aging, 25, 141-151. doi: 10.1353/cja.2006.004.

Tavares, D. M. S., Bolina, A. F., Dias, F. A., Ferreira, P. C. S., \& Haas, V. J. (2014). Quality of life of elderly: comparison between urban and rural areas. Invest Educ Enferm, 32(3), 401-413.

Vogelsang, E. M. (2016). Older adult social participation and its relationship with health : rural-urban diffrences. Health Place, 42, 111-119. doi: 10.1016/j.healthplace.2016.09.010.

Wang, J., \& Zhao. X. (2012). Family functioning and social support for older patients with depression in an urban area of Shanghai, China. Archives of Gerontology and Geriatrics, 55, 574-579. doi : 10.1016/j.archger.2012.06.011.

Wang, M. W., \& Yuang, Y. Y. (2016). Evaluating family function in caring for a geriatric group : family apgar applied for older adults by home care nurses. Geriatr Gerontol Int, 16, 716-721. doi: 10.1111/ggi.12544.

Westerhof, G. J., Bohlmeijer, E. T., \& McAdams, D. P. (2017). The relation of ego integrity and despair to personality traits and mental health. $J$ Gerontol B Psychol Sci Soc Sci, 72, 3, 400-407. doi : 10.1093/geronb/gbv062. 